Jurnal Tarbawi| Volume 1|No 1| ISSN 2527-4082| 37

\title{
PEMBINAAN KEISLAMAN MAHASISWA BERBASIS TUTORIAL
}

\author{
Sulaeman ${ }^{1}$ \\ Pendidikan Agama Islam Fakultas Agama Islam| Unismuh Makassaremail: \\ sulaemanm@unismuh.ac.id
}

\begin{abstract}
ABSTRAK
Penelitian ini bertujuan mendeskripsikan sekaligus menganalisis pembinaan keislaman berbasis tutorial di Unismuh Makassar. Fokus kajiannya adalah bagaimana model tutorial yang diterapkan pada kegiatan pembinaan keislaman, khususnya pada tiga kegiatan, yaitu: pesantren mahasiswa baru, dar al-arqam dasar (DAD), dan perkuliahan al-Islam dan Kemuhammadiyahan (AIK). Jenis penelitian ini adalah kualitatif. Data dikumpulkan melalui wawancara, observasi, dan dokumentasi. Penelitian menunjukkan bahwa ketiga kegiatan tersebut menekankan pengalaman keberislaman dalam kehidupan sehari-hari. Kegiatan tutorial di bidang aqidah menekankan pada purifikasi iman dari syirik, praktik ibadah yang sesuai dengan Himpinan Putusan Tarjih Muhammadiyah, serta akhlak mulia.
\end{abstract}

Kata Kunci: Pembinaan keislaman mahasiswa, tutorial.

\section{ABSTRACT}

This study aims to describe as well as analyzing the development of Islamic-based tutorial on Makassar Muhammadiyah University. The focus of study is how to model the tutorial that is applied to the activities of Islamic guidance, particularly on three activities, namely: boarding school freshman, Al-Arqam basic training (DAD), and the subject used al-Islam and Kemuhammadiyahan (AIK). This type of research is qualitative. Data were collected through interviews, observation, and documentation. Research shows that three of these activities emphasize Islamic experience in the life. Tutorial activities of Aqeedah is emphasizes the purification of faith and shirk, the worship practices in accordance with decision Himpunan Tarjih Muhammadiyah, and good behavior.

Keywords: Islamic Guidance student, tutorial. 


\section{PENDAHULUAN}

Pembinaan kehidupan keislaman di universitas merupakan hal yang penting. Ini didasarkan pada tujuan pendidikan nasional yang dirumuskan dalam Undang-Undang Republik Indonesia Nomor 20 Tahun 2003 tentang Sistem Pendidikan Nasional bab II pasal 3:

Pendidikan nasional berfungsi mengembangkan kemampuan dan membentuk watak atau peradaban bangsa yang bermartabat dalam rangka mencerdaskan kehidupan bangsa, bertujuan untuk berkembangnya potensi peserta didik agar menjadi manusia yang beriman dan bertakwa kepada Tuhan Yang Maha Esa, berakhlak mulia, sehat, berilmu, cakap, kreatif, mandiri, dan menjadi warga negara yang demokratis serta bertanggung jawab.

Berdasarkan tujuan pendidikan nasional di atas, jelas bahwa iman dan takwa adalah nilai inti sekaligus menjadi cita-cita pertama yang ingin diwujudkan melalui pelaksanaan pendidikan nasional. Hal tersebut menegaskan pula bahwa konsepsi yuridis pendidikan nasional sangat mendukung adanya praktik dan lembaga pendidikan yang berbasis pada nilai-nilai agama (Islam).

Universitas Muhammadiyah (Unismuh) Makassar hadir untuk merealisasikan cita-cita pendidikan nasional di atas, termasuk pula cita-cita K.H. Ahmad Dahlan (pendiri Muhammadiyah), sebagaimana dikutip Hamdan (2009), supaya lahir manusia baru yang mampu tampil sebagai ulama- intelek atau intelek-ulama, yaitu seorang muslim yang memiliki keteguhan iman dan ilmu yang luas. Cita-cita ini tercermin dalam Statuta Unismuh bab III pasal 7 ayat 1 dan 2, bahwa Unismuh merupakan perguruan tinggi yang berasaskan Islam, berfungsi sebagai pencetak akademisi yang berjiwa tauhid sebagai pemandu dan pencerah kepada seluruh lapisan dalam kehidupan bermasyarakat.

Upaya untuk mewujudkan citacita di atas telah dilakukan oleh Unismuh Makassar melalui berbagai kegiatan pembinaan keberagamaan mahasiswa. Namun secara faktual, kehidupan keberagamaan mahasiswa Unismuh Makassar belum seutuhnya sesuai dengan yang dicita-citakan. Dapat dikatakan bahwa kegiatan-kegiatan pembinaan yang dilaksanakan belum efektif mengembangkan kualitas keberagamaan mahasiswa.

\begin{tabular}{lrr}
\multicolumn{2}{c}{ Fenomena } & \multicolumn{2}{r}{ keberagamaan } \\
mahasiswa & Unismuh & yang \\
memperlihatkan bahwa tingkat & baharasan \\
keberagamaan mereka masih harus \\
ditingkatkan adalah: (1) terdapat
\end{tabular}
mahasiswa yang tidak dapat membaca Al-Qur'an secara benar; (2) terdapat mahasiswa yang tidak mengindahkan azan, malah ketika waktu salat tiba mereka masih bercengkerama atau melakukan aktivitas lainnya (3) terdapat mahasiswa yang tidak memahami arti bacaan salat; (4) terdapat mahasiswi yang mengenakan busana tidak sesuai standar; dan (5) terdapat mahasiswa berperilaku anarkis, baik dalam bentuk perkelahian antar mahasiswa, maupun dalam bentuk demonstrasi yang merusak fasilitas kampus, menutup jalan atau yang merugikan kepentingan umum. 
Gambaran di atas menunjukkan adanya kesenjangan antara harapan dan kenyataan. Pada tataran ideal, semestinya mahasiswa Unismuh Makassar menjadi mahasiswa yang paling agamais, karena mereka menempuh pendidikan pada perguruan tinggi yang berciri keislaman dengan sejumlah program pembinaan. Namun pada tataran realitas, kondisi keberagamaannya tidak berbeda dengan fenomena yang terjadi pada perguruan tinggi umum. Pada konteks inilah, pembinaan keislaman mahasiswa berbasis tutorial di Unismuh Makassar patut dikaji.

Pembinaan berbasis tutorial merupakan kegiatan khusus yang menekankan pada pendalaman dan penguasaan aspek fundamental dalam Islam, seperti aqidah, akhlak, keterampilan praktik ibadah, dan baca tulis al-Quran. Secara teori, kegiatan tutorial dalam pembinaan keislaman ini relevan dengan model belajar cooperative learning karena dilaksanakan dalam bentuk sistem kerja/belajar kelompok yang terstruktur. Syukri (2006: 16) menjelaskan, tutor berasal dari teman sebaya, artinya dilakukan dengan prinsip belajar bersama. Pada praktiknya, tutorial pembinaan di Unismuh Makassar merupakan sarana menyebarkan nilainilai Islam yang bertujuan untuk memberikan pendalaman dan penguasaan keislaman bagi mahasiswa di luar materi perkuliahan al-Islam Kemuhammadiyah. Dengan pembinaan keislaman berbasis tutorial diharapkan terbentuk sosok pribadi muslim yang utuh, tangguh, menjadi teladan dan sanggup menyebarkan dakwah Islam
(Agent of Change and inovation) kepada warga kampus maupun masyarakat umum.

\section{METODE PENELITIAN}

Penelitian ini diorientasikan untuk mengungkap tentang pembinaan keislaman mahasiswa berbasis tutorial di Unismuh Makassar. Jenis penelitian ini adalah kualitatif deskriptif. Penelitian dilakukan dengan menggunakan pendekatan fenomenologis dan interaksi simbolis. Data diperoleh melalui observasi, pendokumentasian, dan wawancara terhadap dosen serta fungsionaris Ikatan Mahasiswa Muhammadiyah, yang ditentukan secara purposive. Teknik analisis data menggunakan model interaktif Miles dan Huberman, yaitu reduksi data, penyajian data, verifikasi dan kesimpulan.

\section{HASIL DAN PEMBAHASAN}

Kegiatan pembinaan keislaman yang menerapkan model tutorial di Unismuh Makassar terdiri dari: (1) Pesantren Mahasiswa Baru; (2) pengaderan Dar al-Arqam Dasar (DAD) Ikatan Mahasiswa Muhammadiyah (IMM); (3) perkuliahan al-Islam dan Kemuhammadiyahan (AIK).

\section{Pesantren Mahasiswa Baru}

Pesantren Mahasiswa Baru merupakan alternatif penyambutan mahasiswa baru yang sebelumnya sarat dengan kekerasan dan tidak mencerdaskan, menjadi tradisi penyambutan mahasiswa baru yang lebih bermartabat. Samhi Muawwan Djamal (wawancara, 2012) menjelaskan: 
Pesantren Mahasiswa Baru menghilangkan kebiasaankebiasaan anarkis dan budaya penjajahan mahasiswa senior kepada juniornya. Dengan kegiatan ini, acara penyambutan mahasiswa baru diisi dengan memberikan kesadaran kepada mahasiswa baru bahwa seperti inilah dunia kampus yang sebenarnya, bernuansa akademik dan islami, bukan seperti yang dulu, yang toleran terhadap budaya kekerasan.

Pesantren Mahasiswa Baru mengenalkan sisi fundamental keberagamaan, seperti iman yang benar, ibadah yang tertib, dan akhlak yang terpuji. Pada pelaksanaannya, setiap kelompok peserta didampingi oleh satu orang pemandu kelas dan dua orang pendamping, yang keseluruhannya bertindak sebagai tutor. Pemandu kelas berasal dari unsur dosen dengan tugas utama menjadi nara sumber, pembimbing, dan pengarah acara di kelas. Adapun pendamping terdiri dari fungsionaris lembaga kemahasiswaan Unismuh, yaitu Badan Eksekutif Mahasiswa (BEM) dan IMM. Tugas pendamping adalah mengarahkan dan mendampingi kelompok dalam hal administrasi, perlengkapan, dan kegiatan bimbingan ibadah praktis, baik di dalam maupun di luar kelas.

Berdasarkan pengamatan penulis, kegiatan tutorial terutama dilakukan dalam bentuk bimbingan dan praktik qiraah, taharah, dan salat. Bimbingan qiraah diawali dengan penjelasan singkat oleh pemandu mengenai hukum-hukum bacaan (tajwid). Selanjutnya, pemandu dan pendamping membimbing peserta satu per satu untuk membaca Al-Qur'an. Pada proses bimbingan qiraah ini, diidentifikasi tingkat kemampuan peserta dalam membaca Al-Qur'an. Dari identifikasi itu, peserta diklasifikasi berdasarkan tingkat kemampuannya dalam membaca Al-Qur'an. Hasil identifikasi tersebut dijadikan bahan rekomendasi untuk pembinaan selanjutnya.

Penulis juga mengamati bahwa bimbingan taharah yang dilakukan mencakup tata cara istinja, tata cara mandi wajib, praktik berwudu, dan tayammum. Sedangkan bimbingan salat berkaitan tata cara salat, seperti gerakan dan bacaan salat serta tata cara masbuk. Pada kegiatan ini, peserta diharapkan dapat mempraktikkan taharah dan salat sesuai buku Himpunan Putusan Tarjih (HPT) Muhammadiyah.

\section{Dar al-Arqam Dasar (DAD)}

Dar al-Arqam Dasar (DAD) merupakan salah satu jenjang pengaderan yang diselenggarakan oleh Ikatan Mahasiswa Muhammadiyah (IMM). Dalam buku Sistem Perkaderan IMM disebutkan: "DAD adalah komponen pengaderan utama tingkat pertama yang merupakan prasyarat bagi calon pimpinan IMM tingkat komisariat."

Nama Dar al-Arqam dinisbahkan pada sahabat nabi, Arqam ibn Abi alArqam, yang rumahnya digunakan oleh Rasulullah saw. sebagai tempat untuk membina para sahabatnya. Dari tempat ini lahir generasi Islam pertama, seperti Abu Bakar al-Siddiq, Usman ibn Affan, 'Ali ibn Abi Talib, Khadijah, Zaid ibn Sabit, dan sahabat yang lain. IMM 
memandang bahwa pembinaan yang dilakukan oleh Rasulullah saw adalah model ideal yang harus dicontoh dalam melakukan pembinaan generasi muslim.

Keikutsertaan mahasiswa Unismuh dalam pengaderan IMM, khususnya DAD, menjadi salah satu syarat akademik, artinya semua mahasiswa harus mengikuti DAD, dan dianjurkan sejak awal, meskipun kenyataannya karena jumlah mahasiswa banyak, maka terkadang nanti semester IV baru ikut. Piagam atau tanda lulus DAD menjadi salah satu syarat yang harus dipenuhi oleh mahasiswa untuk mengikuti kuliah kerja profesi (KKP) dan PPL

Kegiatan tutorial dalam proses DAD difokuskan pada aspek-aspek keberagamaan yang dibina, yaitu:

\section{1) Aspek ideologis}

Pembinaan aspek ideologis yang dimaksud di sini adalah ideologi yang berbasis tauhid. Bahwa keyakinan, pandangan, dan tujuan hidup seorang muslim harus berorientasi pada keesaan Allah swt. Pembinaan pada aspek ini dilakukan melalui penyajian dan pendalaman materi tauhid serta kajian ayat-ayat Al-Qur'an yang relevan. Kajian ayat yang dimaksud dilaksanakan setelah salat subuh dan magrib.

Ajaran tauhid meniscayakan penolakan terhadap syirik. Itulah sebabnya dalam DAD, peserta disterilisasi dari unsur-unsur kemusyrikan. Berdasarkan pengamatan penulis, cara yang ditempuh untuk mengidentifikasi peserta yang berperilaku syirik adalah pengakuan dari peserta atau dilakukan investigasi dan interogasi. Cara ini mengadaptasi model konseling dalam dunia psikologi.

Penulis mengamati pula, bahwa penanaman ideologi tauhidiah yang dilakukan di DAD dominan menggunakan metode indoktrinasi. Metode ini telah lama digunakan dalam proses DAD, dan cukup berhasil melahirkan kader-kader yang puritan. Hanya saja, ini perlu diimbangi dengan pendekatan filsafat, sebab tahap perkembangan kesadaran beragama mahasiswa berada pada tahap kepercayaan individual-reflektif. Menurut Zakiah Darajat (2005), tahap ini ditandai oleh lahirnya kesadaran kritis untuk merefleksi seluruh pendapat, keyakinan, dan nilai (religius) lama. Berpijak dari hal ini, dapat dikatakan bahwa model keberimanan mahasiswa adalah keberimanan yang kritis. Oleh karena itu, doktrin tauhid sejatinya tidak cukup dengan dogma dan penjelasan secara naqli, tetapi memerlukan penjelasan akli, yang logis dan ilmiah.

\section{2) Aspek ritual}

Aspek ritual yang dibina dalam DAD adalah ibadah mahdah, khususnya taharah dan salat. Aspek ritual ini menjadi target pembinaan pada fase kedua, yaitu peserta dipandu untuk melaksanakan ibadah dengan ber-ittiba pada keputusan tarjih Muhammadiyah. Di sini, tata cara taharah dipraktikkan, bacaan salat dihafal dan dipahami artinya.

Metode pembinaan yang diterapkan adalah pembiasaan dan peneladanan. Peserta dibiasakan salat wajib secara berjamaah, salat sunah rawatib, dan salat tahajjud. Adapun bentuk peneladanannya adalah 
instruktur, pimpinan komisariat, dan panitia DAD harus pula melakukan ibadah seperti yang diharuskan kepada peserta.

\section{3) Aspek intelektual.}

Pembinaan aspek intelektual artinya upaya peningkatan pengetahuan dan pemahaman peserta terhadap ajaran Islam. Dalam konteks ini, ajaran Islam yang dimaksud adalah meliputi tauhid, ibadah, dan akhlak.

Jika pembinaan aspek intelektual diartikan sebagai peningkatan kemampuan metodologis peserta untuk memahami ajaran Islam, maka itu terjadi pada penyajian dan pendalaman materi filsafat ilmu dan materi metodologi studi Islam.

\section{4) Aspek eksperiensial}

Aspek eksperiensial berkaitan tingkat seseorang dalam merasakan pengalaman-pengalaman keagamaan. Aspek ini bersifat afektif, yaitu adanya keterlibatan emosional pada pelaksanaan ajaran agama. Dalam DAD, pembinaan aspek ini dapat dilihat pada pengalaman melaksanakan salat wajib dan salat sunah, terutama salat tahajjud.

Penulis mengamati, dalam rangka pembinaan aspek ini, maka peserta DAD diharuskan untuk menghafal dan memahami arti bacaan dan gerakan salat. Berkaitan dengan ini, Ya'kub (wawancara, 2012) menjelaskan, "ibadah salat akan menjadi sebuah pengalaman spiritual yang nikmat kalau dilakukan dengan khusyuk. Salah satu cara untuk khusyuk adalah mengerti arti bacaan dan gerakan salat."
5) Aspek konsekuensial

Aspek konsekuensial berkaitan perilaku seseorang dalam kehidupan sosial sebagai refleksi dari ajaran agamanya. Peserta dibimbing untuk berperilaku sesuai tuntunan akhlak Islam. Terhadap peserta yang dianggap berakhlak baik diberikan penguatan (inforcement). Adapun peserta yang dianggap bermasalah, maka ditangani secara khusus melalui metode secrening. Istilah secrening dalam DAD diartikan sebagai metode mengubah sikap mental dan perilaku peserta ke arah yang lebih baik.

Pembinaan akhlak mahasiswa membutuhkan pendekatan khusus, mengingat mahasiswa berada pada tahap perkembangan moral yang cenderung untuk mengabaikan aturan institusi dan konvensi masyarakat, yang diistilahkan Erikson (2010), lebih menuruti kata hati dibanding aturan hukum. Contoh yang tepat untuk ini adalah perilaku mahasiswa yang melakukan demonstrasi. Para demonstran menganut sebuah prinsip: "jika kebenaran dan kebaikan harus disampaikan dengan cara melanggar aturan, maka langgarlah aturan itu!" Aturan boleh dilanggar demi menyuarakan kata hati. Persoalannya adalah apakah kata hati mahasiswa merupakan suara kebenaran? Yunahar Ilyas (2011) mengemukakan, kata hati itu relatif, karena itu tidak dapat jadikan ukuran untuk menentukan benar atau baik. Ukuran yang pasti tentang baik atau buruk adalah Al-Qur'an dan hadis. Maka seyogyanya sumber utama dalam pembinaan akhlak merujuk kepada AlQur'an dan hadis, bukan kata hati, pikiran, dan tradisi masyarakat. 
Perkuliahan AIK

Mata kuliah AIK terdiri dari AIK I sampai AIK VIII, diajarkan sesuai level semester. Mata kuliah AIK mempunyai hubungan timbal balik dengan mata kuliah lain. AIK memotivasi dan memberi panduan etik untuk mendalami ilmu yang ditekuni mahasiswa. Sebaliknya, dengan memahami ilmu yang lain diharapkan menginspirasi dan menjadi "pisau analisis" untuk membedah atau memahami ajaran Islam.

Pelaksanaan tutorial AIK berlangsung pada semester 1 dan 2 melalui program Gerakan Jamaah dan Dakwah Jamaah (GJDJ). Program wajib ini untuk mahasiswa peserta mata kuliah AIK di Unismuh Makassar, dimaksudkan sebagai pengayaan pengalamaan dan pengamalan ajaran agama Islam, yaitu pada aspek: (a) Aqidah Islam, yakni hal-hal yang berkaitan dengan keimanan kepada Allah, serta implementasinya dalam kehidupan sosial. (b) Ibadah, yakni materi yang berkaitan dengan tata cara pelaksanaan ibadah khusus (ritual), seperti salat dan puasa, serta berbagai ibadah sunnah. (c) Akhlak, yakni materi yang berkaitan dengan tata cara hubungan yang baik antara sesama manusia, alam, dan dengan Allah.

Dari tiga kegiatan yang telah dikemukakan (Pesantern Maba, DAD, dan perkuliahan AIK), terdapat beberapa materi yang diulang-ulang, misalnya akidah, ibadah, dan akhlak. Menanggapi hal ini, Mustaqim Muhallim (wawancara, 2012) menjelaskan:

Pengulangan itu perlu, sesuatu hal yang dianggap penting apalagi berkaitan dengan penanaman nilai, pengulangan itu akan semakin menguatkan. Sebab, pada satu kesempatan tidak semua yang hendak ditransformasikan akan tercapai, maka pada kesempatan lain diharapkan tercapai. Meski terjadi pengulangan, tetapi diharapkan penekanannya berbeda. Diharapkan selalu ada pengayaan dari yang sudah diketahui sebelumnya, dan supaya tidak membosankan, maka metodenya yang perlu divariasikan.

Pendapat Mustaqim Muhallim tersebut logis dan dapat diterima, dengan syarat pengulangan materi yang terjadi memang direncanakan (by design). Sebab kalau direncanakan, meskipun materi sama, tetapi aspek penekanan dan muatan yang hendak dicapai dalam setiap penyajian materi tersebut akan berbeda. Namun jika pengulangan justru terjadi secara kebetulan (by accident), maka ini menunjukkan bahwa wacana keislaman yang dikembangkan pada setiap kegiatan hanya berputar pada masalah purifikasi akidah, masalah akhlak pergaulan dan berbusana, serta masalah taharah dan salat yang sesuai HPT.

\section{KESIMPULAN}

Model tutorial dalam pembinaan keberagamaan mahasiswa di Unismuh Makassar dilakukan dalam bentuk: (a) Pesantren Mahasiswa Baru, yang mengenalkan sisi fundamental keberagamaan, seperti iman yang benar, ibadah yang tertib, dan akhlak yang terpuji. (b) Dar al-Arqam Dasar (DAD), 
yang membina aspek keberagamaan seperti yang ditekankan pada Pesantren Mahasiswa Baru, tetapi dengan muatan yang lebih komplet, dan proses yang lebih terpola. (c) Perkuliahan AIK, yang membelajarkan mahasiswa tentang berbagai aspek ajaran Islam, tetapi lebih berorientasi kognitif. Pada dasarnya, pelaksanaan tiga kegiatan tersebut masih terdapat kekurangan, bahkan efektivitasnya perlu dievaluasi dan diteliti.

\section{DAFTAR PUSTAKA}

Dewan Pimpinan Pusat IMM. 2011. Sistem Perkaderan IMM. Cet. I; Jakarta: DPP IMM.

Erikson, Erik H. 2010. Childhood and Society, terj. Helly Prajitno Soetjipto dan Sri Mulyantini Soetjipto. Cet. I; Yogyakarta: Pustaka Pelajar.

Hamdan. 2009. Paradigma Baru Pendidikan Muhammadiyah. Cet. I; Yogyakarta: Ar-ruzz Media.

Ilyas, Yunahar. 2011. Kuliah Akhlak, Cet. XI; Yogyakarta: Lembaga Pengkajian dan Pengamalan Islam.

Republik Indonesia. 2011. UndangUndang RI Nomor 20 Tahun 2003 tentang Sistem Pendidikan Nasional. Cet. IV; Jakarta: Sinar Grafika.

Zakiah Daradjat. 2005. Ilmu Jiwa Agama. Cet. XVII; Jakarta: Bulan Bintang. 